\title{
A comparison between two- and six-row winter barley genotypes for above-ground dry matter production and distribution
}

\author{
J Le Gouis \\ INRA, Laboratoire de Génétique et d'Amélioration des Plantes, F-80200 Estrées-Mons, France
}

(Received 24 June 1991; accepted 22 November 1991)

\begin{abstract}
Summary - A comparison between 2- and 6-row winter barley genetoypes was carried out in 1989 and 1990 at the plant breeding station of Estrées-Mons (Somme, France). The above-ground dry matter (DM) and nitrogen $(\mathrm{N})$ production and distribution were studied at anthesis and at harvest in 22 genotypes in 1989 (11 2-row and 11 6-row) and 31 genotypes in 1990 (15 2-row and 16 6-row) representing the most widely grown winter barley cultivars in France. The average grain yields were high (751 and $839 \mathrm{~g} . \mathrm{m}-2$ in 1989 and 1990) thus allowing a comparison of the genotypes at a high level of production. In both years, the 6-row outyielded the 2-row by about $7 \%$. This difference results from their superior DM production $(+2.5 \%$ on average) and harvest index (49.3 vs 47.4$)$. The 6-row have a higher DM production due to their larger ear dry matter from anthesis onwards. Neither the duration of the sowing-anthesis period nor the leaf area index can explain this difference. Post-anthesis assimilation is quite similar for the 2 types. The 6-row have a better harvest index despite their greater height and the existence of a negative correlation between height and harvest index within each group. Grain $\mathbf{N}$ yields are similar. The higher grain yield of 6-row genotypes compensates for their lower grain $\mathrm{N}$ concentration.
\end{abstract}

Hordeum vulgare L barley / two-row barley / six-row barley / above-ground dry matter / nitrogen / harvest index

Résumé - Une comparaison entre orges d'hiver à 2 rangs et à 6 rangs pour la production et la répartition de la matière sèche aérienne. Une comparaison entre orges d'hiver à 2 rangs et à 6 rangs a été réalisée en 1989 et 1990 à la station d'amélioration des plantes d'Estrées-Mons (Somme, France). La production et la répartition de la matière sèche aérienne et de l'azote ont été étudiées à la floraison et à la maturité sur 22 génotypes en 1989 (11 deux rangs et 11 six rangs) et 31 génotypes en 1990 (15 deux rangs et 16 six rangs) représentant une large part des surfaces cultivées en orges d'hiver en France. Les rendements moyens en grain ont été élevés (751 et $839 \mathrm{~g} . \mathrm{m}^{-2}$ en 1989 et 1990) réalisant l'objectif de comparer les génotypes à des niveaux élevés de production. Les orges à six rangs ont obtenu les 2 années un rendement en grain supérieur à celui des 2 rangs de environ $7 \%$. Cet écart est dû à la fois à leur production de matière sèche $(+2.5 \%$ en moyenne) et à leur indice de récolte (49.3 contre 47.4). Dès la floraison, les 6 rangs ont une matière sèche aérienne supérieure et ceci grâce à leur matière sèche des épis. Ni la durée semis-floraison, ni l'indice foliaire n'expliquent cette différence. L'assimilation postfloraison est semblable pour les 2 types d'orge. L'indice de récolte des 6 rangs est meilleur malgré leur plus grande taille et la corrélation négative étroite qui existe entre ces 2 caractères à l'intérieur de chaque groupe. La quantité d'azote des grains est similaire entre 2 et 6 rangs. En effet, le rendement en grain plus élevé des 6 rangs compense leur faible teneur en azote du grain.

Hordeum vulgare L orge / orge à 2 rangs / orge à 6 rangs / matière sèche aérienne / azote / indice de récolte 


\section{INTRODUCTION}

Cultivated barley (Hordeum vulgare $L$ ) is currently classified according to ear structure as either 2-row or 6-row. Of the 3 spikelets which are inserted at each node of the rachis, only the central one is fertile in the 2-row type. Two independent loci control this characteristic (Gymer, 1978). From an agronomic point of view, the differences which are measurable between the 2 barley types may be due to a pleiotropic effect of these loci but also to the selection, within each group, of a genetic background favourable to their expression (Riggs and Kirby, 1978).

During the period 1985-1990 in France, the 2- and 6-row cultivars represented respectively about 40 and $60 \%$ of the winter barley area. The 2-row usually have a lower number of grains per ear compensated by a higher tillering capacity and 1000-grain weight. Nevertheless, the 6-row often outyield the 2row (Jestin, 1985).

A better understanding of the potential grain yields of 2- and 6-row and of the ways in which their yield is obtained may help the plant breeder in planning his breeding programme: first, in the choice of either one or the other type of barley depending on his objectives; then in the choice of the characteristics which are to be selected within each of the 2 groups. Therefore, over 2 years we observed the production and distribution of the above-ground dry matter (DM) and nitrogen $(\mathrm{N})$ of several genotypes grown in a potentially high-yielding situation.

\section{MATERIALS AND METHODS}

Two experiments with respectively 27 and 36 barley genotypes were carried out in 1988 and 1989 at the plant breeding station of Estrées-Mons (Somme, Northern France). Five varieties with a low yielding potential (as they were unadapted to this area) were not taken into account in the analyses. Except for 1 6-row line (CF 84-234) from the plant breeding programme of the INRA station of Clermont-Ferrand, all the genotypes studied were registered between 1963-1988 (see table in the Appendix). The 221988 genotypes (11 2-row and 11 6-row) and the 311989 genotypes (15 2-row and 16 6-row) represented 82 and $71 \%$ respectively of the winter barley seed production area in 1990 (GNIS, 1990). This set of varieties is therefore quite a good sample of the genetic variability currently existing in the winter barley crop in France. However, any generalization of the results derived from this study to all possible 2- and 6-row should of course be considered with care.

In 1988, the experiment sown on 12 October was a randomized block design with 4 replications. In 1989, the experiment was sown on 6 October in a lattice square design with 4 replications. The soil is a deep silt loam. Measured at the beginning of stem elongation, the average numbers of plants were $209 \mathrm{~m}^{-2}$ in 1989 and $260 \mathrm{~m}^{-2}$ in 1990 . Nitrogen fertilizer was applied according to a predictive balance sheet method with an objective of 90 q.ha ${ }^{-1}$ (145 and $170 \mathrm{~kg}$ of $\mathrm{N}$ per ha respectively in 1989 and 1990). Pesticide treatments were applied in order to achieve a total control of parasites. One growth regulator spraying in 1989 (670 g.ha ${ }^{-1}$ mepiquat chloride +340 g.ha ha $^{-1}$ ethephon as 2.2 l.ha ${ }^{-1}$ Terpal) and 2 sprayings in 1990 (2.2 I. ha $\mathrm{I}^{-1}$ Terpal and $480 \mathrm{~g} \cdot \mathrm{ha}^{-1}$ ethephon as $1 \mathrm{l} . \mathrm{ha}^{-1}$ Ethéverse) were performed to limit the risk of lodging. These substances are known to have many effects on growth beside those on height, but their use was found to be necessary in regard to the high grain yields expected.

Each plot consisted of $65-\mathrm{m}$ rows spaced $0.2 \mathrm{~m}$ apart. A single treatment was represented by one plot in 1989 and by 5 adjacent plots in 1990. For each sampling, the 4 central rows were cut at ground level for a length of $1.5 \mathrm{~m}$ in $1989\left(1.2 \mathrm{~m}^{2}\right)$ and $5 \mathrm{~m}$ in $1990\left(4.0 \mathrm{~m}^{2}\right)$ and then weighed. The number of shoots and the above-ground DM were estimated on a $1 \mathrm{~kg}$ of fresh weight basis. The DM distribution between different parts was determined on a minimum of 30 shoots sampled randomly.

Two samples were collected:

- at flowering: this stage was defined as the date on which about $50 \%$ of the ears had visible stamens. The aerial parts were separated into ear, stem (stem + leaf sheath) and leaf lamina. The area of functional leaves (leaves with approximately $50 \%$ of their surface still green) was measured with an electronic area meter ( $\mathrm{Li}-3000 \mathrm{Li}-\mathrm{Cor}$ portable area meter). In 1990, the peduncles (top internode + flag leaf sheath) were also separated and their area measured with the area meter.

- at maturity: it was considered that maturity was attained when no green tissue remained. Before harvest, lodging was recorded on a 9-grade scale ( 1 = no lodging; $9=$ completely lodged). Plant height (from stem base to ear tip) was measured on 15 shoots. The aerial parts were separated into ear, stem, peduncle and leaf lamina. The ears were then threshed, the grains counted and 1000 -grain weight estimated. Chaff and vegetative DM respectively designate non-grain parts of the ear (ie rachis, glumes, awns and 2-row sterile spikelets) and non-grain parts of the shoot. The harvest index is the ratio of grain DM to total above-ground DM. 
For each variety, the percentage of $\mathrm{N}$ (Kjeldahl total $N$ ) in aerial DM at flowering, in grain DM and in vegetative DM at maturity was determined on a mixed sample of the 4 replications.

The proportion of grain yield from pre-anthesis assimilation is estimated by the difference between aerial DM at anthesis and vegetative DM at maturity. This quantity also includes grain DM at anthesis. All the genotypes studied here as well as almost all other cultivated barley varieties have hulled kernels (the lemma and the palea adhere to the caryopsis) and the hulls are already present at this early stage. Post-anthesis assimilation is estimated by the difference between above-ground $D M$ at maturity and at flowering. The origins of grain DM thus calculated rely on 3 hypotheses (Gallagher et al, 1975; Bidinger et al, 1977): absence of any mechanical or respiratory loss; absence of any retranslocation of assimilates from the roots; and transfer of all post-anthesis assimilates to the grain. The same calculation can be applied to the $\mathrm{N}$ part of the grain.

The average flowering dates and $N$ related characteristics of 2- and 6-row have been compared by $t$-test. For the other data, the comparison between 2- and 6-row has been carried out by testing the effect of the row number using a fixed model of variance analysis, as follows:

$$
Y_{i j k}=m+r_{i}+b_{j}+r b_{i j}+g_{i k}+e_{i j k}
$$

where:

$$
\begin{aligned}
m= & \text { general mean; } \\
r_{i}= & \text { number of row (2- or 6-row) } \\
b_{j}= & \text { replication; } \\
r b_{i j}= & \text { interaction between the number of row } \\
& \text { and replication; } \\
g_{i k}= & \text { genotype hierarchized to the number } \\
& \text { of row; } \\
e_{i j k}= & \text { residual. }
\end{aligned}
$$

The AMANCE statistical package (Bachacou et al, 1981) has been used to analyse the data.

\section{RESULTS AND DISCUSSION}

Over the 2-year period, climatic conditions were very similar. They were characterized by mild winters and warm, dry springs. Nevertheless, soil water content measurements completed during grain filling (data unpublished) showed that water was not a limiting factor. The grain yield was superior in 1990 . Otherwise the results are very similar. A larger number of differences were significant in 1990 , more probably due to the lower residual errors on measurements in 1990 than to the experiment particularities (varietal sample, in- tensification level, etc). Therefore the 1990 results will be used in priority to support the discussion.

The mean grain yields were 751 and $839 \mathrm{~g} \cdot \mathrm{m}^{-2}$ (75 and $84 \mathrm{q} \cdot \mathrm{ha}^{-1}$ at $0 \%$ moisture) in 1989 and 1990 respectively. This made it possible to compare the 2- and 6-row at a high grain production level as intended.

\section{Grain yield and yield components}

The 6-row shows a superior grain yield over the 2 years (table I). The difference is about $+7 \%$. It is even higher if only the best 3 varieties of each group are taken into account $(+10.6 \%$ in 1989 and $+12.7 \%$ in 1990).

The levels of yield components are similar to those commonly found for the 2 groups of barley. The number of shoots was higher for the 2-row at anthesis and maturity. But the reverse is true for the number of grains per ear. If the minimum number of rachis nodes is calculated (dividing the number of grains per ear by 1 for the 2-row and 3 for the 6-row), this value is superior for the 2-row (24.7 compared to 15.7 in 1989 and 22.2 against 14.4 in 1990). The 6-row higher ear fertility compensated for their lower number of ears $\mathrm{m}^{-2}$ and their final number of grains $\mathrm{m}^{-2}$ was superior. As regards the known negative correlation between 1000 -grain weight and number of grains $\mathrm{m}^{-2}$, the 6-row 1000 -grain weight was inferior (fig 1). Within each group, the correlation between grain yield and these 2 components is low. High grain yields can be achieved with quite different numbers of grains per $\mathrm{m}^{-2}$ and 1000 -grain weights. In 1990 , a yield of about $950 \mathrm{~g} \cdot \mathrm{m}^{-2}$ was obtained with numbers of grains per $\mathrm{m}^{-2}$ as different as 25000 (Manitou) and 33000 (Barberousse) with corresponding 1000 -grain weights of 38 and 26 respectively (fig 1 ).

\section{Dry matter production and distribution}

The 2 types of barley produce their DM with very different numbers of ears per $\mathrm{m}^{-2}$ : the 2 -row have on average $42 \%$ more than the 6-row. On the basis of a single shoot, the DM of the former is lower (data not communicated, but can be calculated from tables I and II). The same remark can be made if the leaf or 
Table I. Grain yield, yield components, leaf area, plant height and lodging score measured in 1989 and 1990 for the 2- and the 6-row. Within the same year, 2 means followed by the same letter are not significantly different at the $5 \%$ level.

\begin{tabular}{lcccc}
\hline & \multicolumn{2}{c}{1989} & \multicolumn{2}{c}{1990} \\
\cline { 2 - 4 } & 2-row & 6 -row & 2-row & 6 -row \\
\hline Anthesis & $712^{\mathrm{a}}$ & $556^{\mathrm{b}}$ & $937^{\mathrm{a}}$ & $685^{\mathrm{b}}$ \\
No of shoots $\mathrm{m}^{-2}$ & $5.8^{\mathrm{a}}$ & $5.1^{\mathrm{b}}$ & $6.0^{\mathrm{a}}$ & $5.6^{\mathrm{b}}$ \\
Leaf area index & - & - & $0.6^{\mathrm{a}}$ & $0.5^{\mathrm{b}}$ \\
Peduncle area & & & & \\
Maturity & $727^{\mathrm{b}}$ & $775^{\mathrm{a}}$ & $810^{\mathrm{b}}$ & $866^{\mathrm{a}}$ \\
Grain yield $\left(\mathrm{g} \cdot \mathrm{m}^{-2}\right)$ & $704^{\mathrm{a}}$ & $514^{\mathrm{b}}$ & $912^{\mathrm{a}}$ & $626^{\mathrm{b}}$ \\
No of ears $\mathrm{m}^{-2}$ & $24.7^{\mathrm{b}}$ & $47.1^{\mathrm{a}}$ & $22.2^{\mathrm{b}}$ & $43.1^{\mathrm{a}}$ \\
No of grains per ear & $17378^{\mathrm{b}}$ & $23864^{\mathrm{a}}$ & $20160^{\mathrm{b}}$ & $26841^{\mathrm{a}}$ \\
No of grains m $\mathrm{m}^{-2}$ & $42.1^{\mathrm{a}}$ & $32.8^{\mathrm{b}}$ & $40.5^{\mathrm{a}}$ & $32.6^{\mathrm{b}}$ \\
1 OoO-grain weight $(\mathrm{g})$ & $103^{\mathrm{b}}$ & $108^{\mathrm{a}}$ & $101^{\mathrm{b}}$ & $108^{\mathrm{a}}$ \\
Plant height $(\mathrm{cm})$ & $1.2^{\mathrm{a}}$ & $1.3^{\mathrm{a}}$ & $1.9^{\mathrm{b}}$ & $4.3^{\mathrm{a}}$ \\
Lodging score & & & & \\
\hline
\end{tabular}

peduncle area is considered. This agrees with the results of Williams and Hayes (1979) on spring barley. All these results illustrate the negative correlation which often exists between the number of organs and their size.

Thousand-grain weight $(g)$

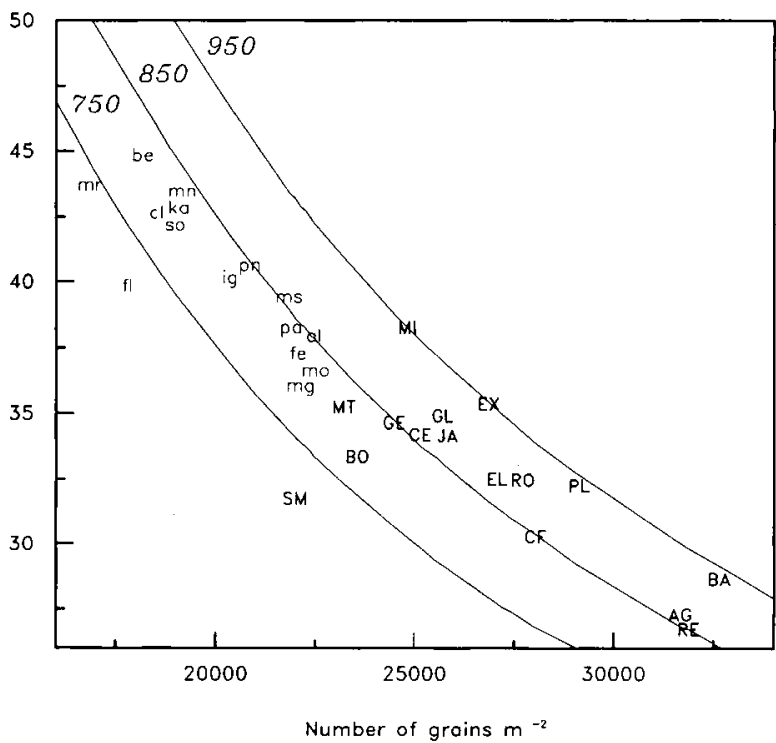

Fig 1. Relation between number of grains $\mathrm{m}^{-2}$ and 1000 grain weight. Each curve represents a given grain yield $\left(750,850\right.$ and $\left.950 \mathrm{~g} \cdot \mathrm{m}^{-2}\right)$. The 6-row are in upper-case, bold type (the varieties are coded according to the table presented in the Appendix).
Estimation of DM on a $\mathrm{m}^{2}$ basis enables observation of the consequences of compensation between the number of shoots and their weight.

The 6-row had a superior aerial DM production at anthesis and maturity for 2 years, the differences being significant in 1990 only (table II). These differences are nevertheless relatively small, averaging about $+2.5 \%$. This result is mainly explained by ear DM. For the leaves and the stem taken together, the 2 groups of barley have the same production of DM.

At anthesis, the 6-row ear DM is higher and the DM of stem + leaves is similar. In 1990 however, there was an inversion of the differences for the peduncle and the rest of the stem: the 2-row peduncle DM was lower and the DM of the rest of the stem was higher.

The average date of anthesis is similar for the 2 groups (table III). Therefore, the duration of the sowing-anthesis period cannot explain the differences observed in DM production, and the same holds true for a comparison of the assimilation areas. The leaf area index and the peduncle area of the 6-row are lower (table I). Their superior leaf area per shoot cannot compensate for their smaller number of shoots per $\mathrm{m}^{-2}$. The fact that there is no relationship between the assimilation area and DM production at anthesis may have several explanations: 
Table II. Aerial DM distribution at anthesis and maturity in 1989 and 1990 for the 2- and the 6-row (1st line: $\mathrm{g} \cdot \mathrm{m}^{-2}$, 2nd line: $\%$ of total dry matter). Within the same year, 2 means followed by the same letter are not significantly different at the $5 \%$ level.

\begin{tabular}{|c|c|c|c|c|c|c|c|c|}
\hline & \multicolumn{4}{|c|}{ Anthesis } & \multicolumn{4}{|c|}{ Maturity } \\
\hline & \multicolumn{2}{|c|}{1989} & \multicolumn{2}{|c|}{1990} & \multicolumn{2}{|c|}{1989} & \multicolumn{2}{|c|}{1990} \\
\hline & 2-row & 6-row & 2-row & 6-row & 2-row & 6-row & 2-row & 6-row \\
\hline Peduncle & - & - & $118^{a}$ & $103^{b}$ & $116^{a}$ & $116^{\mathrm{a}}$ & $123^{a}$ & $114^{b}$ \\
\hline Stem & - & - & $\begin{array}{l}(11.0) \\
526^{b}\end{array}$ & $\begin{array}{l}(9.4) \\
545^{\mathrm{a}} \\
(496)\end{array}$ & $\begin{array}{l}(1.5) \\
446^{a} \\
(290)\end{array}$ & $\begin{array}{l}(1.3) \\
453^{a} \\
(28.6)\end{array}$ & $\begin{array}{l}(7.2) \\
460^{\mathrm{a}} \\
(271)\end{array}$ & $\begin{array}{l}(6.5) \\
468^{a} \\
(069)\end{array}$ \\
\hline Total stem & $\begin{array}{c}619^{\mathrm{a}} \\
(63.8)\end{array}$ & $\begin{array}{c}630^{a} \\
(63.6)\end{array}$ & $\begin{array}{l}644^{\mathrm{a}} \\
(60.0)\end{array}$ & $\begin{array}{l}648^{\mathrm{a}} \\
(59.0)\end{array}$ & $\begin{array}{l}562^{\mathrm{a}} \\
(36.5)\end{array}$ & $\begin{array}{c}569^{\mathrm{a}} \\
(35.9)\end{array}$ & $\begin{array}{c}583^{a} \\
(34.3)\end{array}$ & $\begin{array}{c}582^{\mathrm{a}} \\
(33.4)\end{array}$ \\
\hline Lamina & $\begin{array}{c}216^{a^{\prime}} \\
(22.3)\end{array}$ & $\begin{array}{l}207^{a} \\
(20.9)\end{array}$ & $\begin{array}{l}284^{\mathrm{a}} \\
(26.5)\end{array}$ & $\begin{array}{l}288^{\mathrm{a}} \\
(26.2)\end{array}$ & $\begin{array}{l}138^{a} \\
(9.0)\end{array}$ & $\begin{array}{l}133^{\mathrm{a}} \\
(8.4)\end{array}$ & $\begin{array}{c}189^{\mathrm{a}} \\
(11.1)\end{array}$ & $\begin{array}{c}181^{b^{\prime}} \\
(10.4)\end{array}$ \\
\hline Chaff & & & & & $\begin{array}{l}113^{a} \\
(7.3)\end{array}$ & $\begin{array}{l}105^{a} \\
(6.6)\end{array}$ & $\begin{array}{l}118^{a} \\
(6.9)\end{array}$ & $\begin{array}{l}113^{b} \\
(6.5)\end{array}$ \\
\hline Grain & & & & & $727^{6}$ & $775^{\mathrm{a}}$ & $810^{\mathrm{b}}$ & $866^{\mathbf{a}}$ \\
\hline Total ear & $\begin{array}{c}134^{b} \\
(13.8)\end{array}$ & $\begin{array}{c}153^{\mathrm{a}} \\
(15.5)\end{array}$ & $\begin{array}{c}145^{b} \\
(13.5)\end{array}$ & $\begin{array}{c}162^{\mathrm{a}} \\
(14.7)\end{array}$ & $\begin{array}{c}(47.2) \\
841^{\mathrm{b}} \\
(54.5)\end{array}$ & $\begin{array}{c}(49.0) \\
881^{a} \\
(55.6)\end{array}$ & $\begin{array}{c}(47.6) \\
928^{b} \\
(54.6)\end{array}$ & $\begin{array}{c}(49.7) \\
980^{\mathrm{a}} \\
(56.2)\end{array}$ \\
\hline $\begin{array}{l}\text { Total } \\
\text { Vegetative }\end{array}$ & & & & & $\begin{array}{c}813^{a} \\
(52.8)\end{array}$ & $\begin{array}{c}807^{a} \\
(51.0)\end{array}$ & $\begin{array}{c}889^{a} \\
(52.3)\end{array}$ & $\begin{array}{c}876^{\mathrm{a}} \\
(50.3)\end{array}$ \\
\hline Total & $\begin{array}{c}970^{\mathrm{a}} \\
(100.0)\end{array}$ & $\begin{array}{r}990^{\mathrm{a}} \\
(100.0)\end{array}$ & $\begin{array}{c}1073^{b} \\
(100.0)\end{array}$ & $\begin{array}{c}1099^{a} \\
(100.0)\end{array}$ & $\begin{array}{c}1540^{a} \\
(100.0)\end{array}$ & $\begin{array}{c}1582^{a} \\
(100.0)\end{array}$ & $\begin{array}{c}1700^{6} \\
(100.0)\end{array}$ & $\begin{array}{c}1742^{a} \\
(100.0)\end{array}$ \\
\hline
\end{tabular}

Table III. Mean comparison for flowering date and $N$ related variables in 1989 and 1990 for the 2- and the 6-row (1st line: treatment mean, 2nd line: standard error). Within the same year and the same sampling date, 2 means followed by the same letter are not significantly different at the $5 \%$ level.

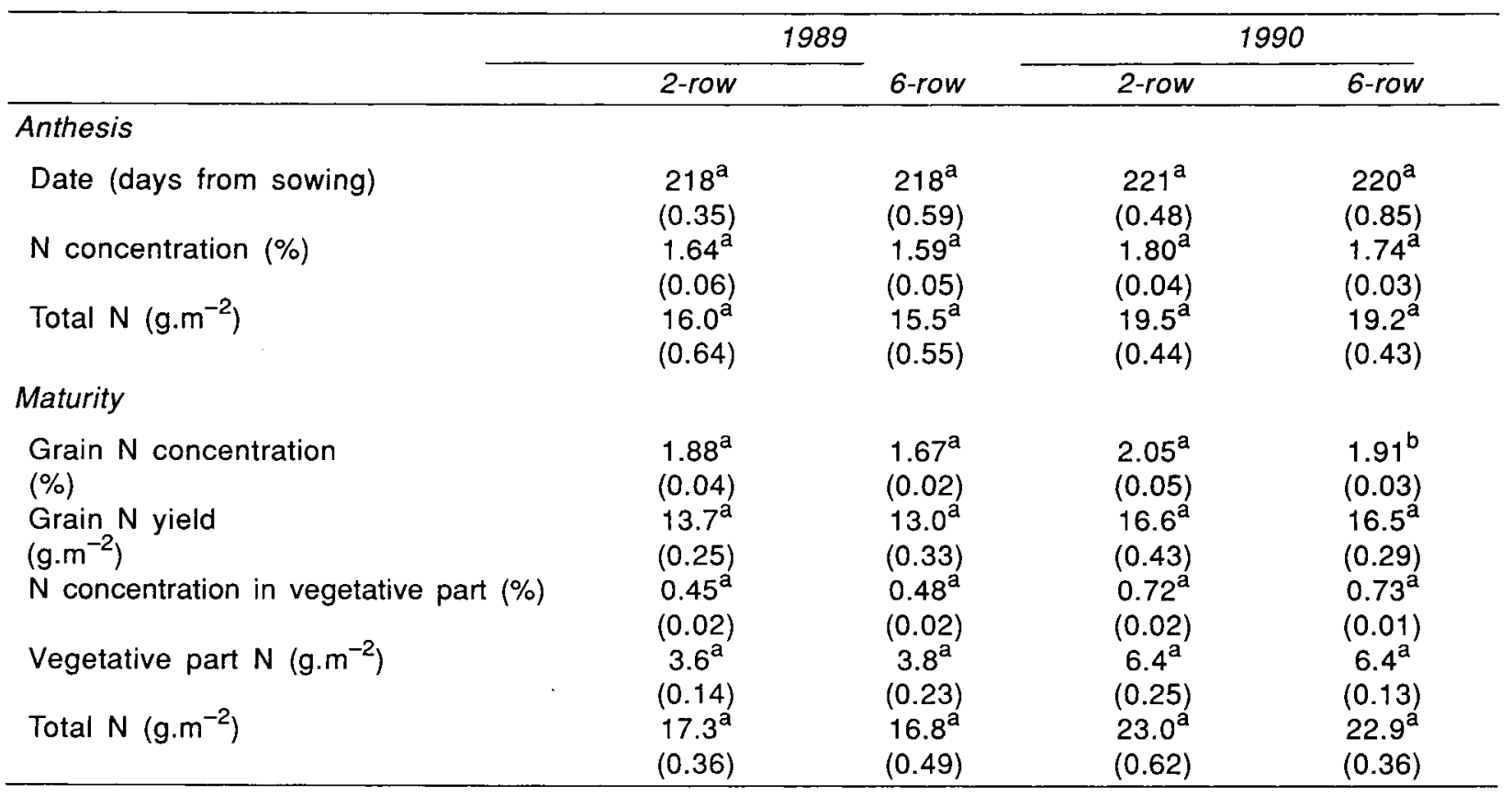


- the measurements available are only an approximation of the true photosynthetically active area. In addition to the leaf area index, canopy structure (heterogeneity, leaf angle, shading) plays an important role in light interception (Varlet-Grancher et al, 1989). It has also been shown that ears and awns are very active sources of photosynthates (Thorne, 1963; Nalbzorczyk et al, 1981). However, even if the DM difference at flowering is due to the ear DM, the short period between heading and anthesis during which ears are exposed to light provides little support for this explanation.

- light interception is not a limiting factor. The estimated leaf area index which is sufficient for a cereal to intercept all solar radiation is very variable from one author to another: from 4.5 (Hipps et al, 1983) to 10 (Russel and Ellis, 1988). With leaf area indices near 6 and a difference as low as $10 \%$, it is quite difficult to reach a conclusion. Moreover, even if the leaf area at flowering is a good indicator of the maximal leaf area, canopy installation dynamics certainly plays an important role which has not been considered in the present study.

At maturity, the vegetative DM is quite similar for the 2 types (table II). As the 6-row have a superior grain yield, their harvest index is also better. This is in agreement with the results of Williams and Hayes (1979). Dry matter distribution is slightly different: the lamina, peduncles and chaff are heavier in the 2-row. The presence of sterile lateral spikelets and a higher number of rachis nodes may explain the higher chaff DM of the 2row.

The 6-row are taller (table I). Takahashi et al (1976) have studied 68 pairs of isogenic lines for the 2-row/6-row character. They have shown that it is the genetic background and not the genes which control the spike structure that is predominant in determining plant height. The higher 6-row lodging susceptibility, mainly visible in 1990, is certainly due in part to their heavier ears associated with a longer straw. The better harvest index of the 6-row is all the more remarkable with regard to the relation between plant height and harvest index (fig 2). Within each group, this relation is strongly negative. This correlation has already been noted by Austin et al (1980) for 2-row spring barley. If 2 varieties are ignored (Mosar, a 2-row only studied in 1990, and Eldorado, a 6-row studied both years), the cor- relation coefficients are $-0.76^{\star *}(9 \mathrm{df})$ and $0.65^{* *}(8 \mathrm{df})$ in 1989 and $-0.91^{* *}(13 \mathrm{df})$ and $-0.89^{\circ *}(14 \mathrm{df})$ in 1990 for the 2-row and the 6 -row respectively. The regression lines are parallel for the 2 years, as their regression coefficients are not significantly different $(P<0.05)$.

The special reaction of the cultivar Mosar is certainly due to its very high tillering capacity $\left(1170 \pm 51\right.$ ears per $\mathrm{m}^{-2}$ at maturity in 1990) which distinguishes it from all the other genotypes. This is related to a high vegetative DM and thus a low harvest index. In contrast, the cultivar Eldorado shows no particular distinctive characteristics, so no explanation can be given for its special behaviour. These 2 examples show that even if the negative correlation between plant height and harvest index seems to be the rule ( 29 genotypes out of 31), some exceptions do exist. It might be of interest to study this relation in other situations (other genotypes and other agricultural practices, without growth regulators for example) in order to better define its limits.

\section{Nitrogen content}

At anthesis, the nitrogen percentage in aerial $D M$ is equivalent in the 2- and the 6-row

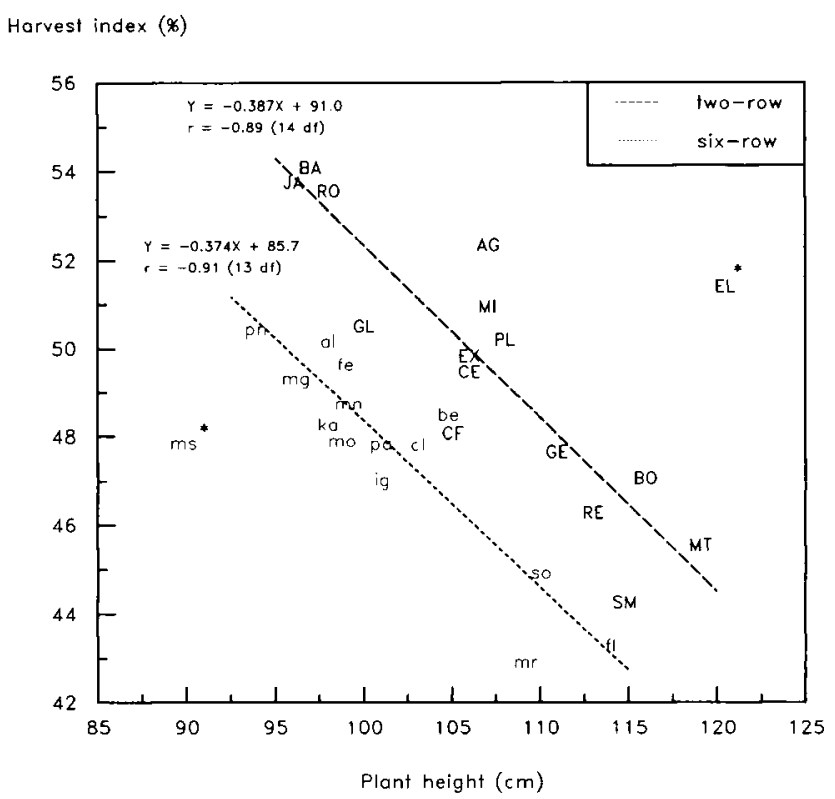

Fig 2. Relation between plant height and harvest index in 1990. The 2 varieties labelled with an asterisk (El and $\mathrm{ms}$ ) were ignored during regression analysis. The regression coefficients are not significantly different at the $5 \%$ level. The 6-row are in uppercase, bold type (the varieties are coded according to the table presented in the Appendix). 
(table III). In spite of a higher DM production for the 6-row, the quantities of $\mathrm{N}$ in the vegetative $D M$ are not significantly different. At maturity, the quantities and the percentages of $\mathrm{N}$ in the vegetative DM are also similar. On the other hand, the concentration of $\mathrm{N}$ in the grain of the 2-row is higher. The superior grain yield of 6-row compensates for their lower $N$ percentage in the grain and final production of $\mathrm{N}$ per ha is equivalent. The $\mathrm{N}$ harvest index is therefore similar for the 2 groups $(75.5 \%$ and $74.5 \%$ on average over the 2 years for the 2-row and 6-row respectively). This result is an illustration of the general negative relation between protein concentration and grain yield (Scriban et al, 1981). It is important to note that several studies carried out with pairs of isogenic lines for the 2-row 6 -row character have revealed a correlation between the 2-row phenotype and a high protein concentration (Pomeranz et al, 1973; McGuire and Hockett, 1983). Compared with their corresponding 6-row lines however, the 2-row lines also often have a lower grain yield.

\section{The origin of grain dry matter}

It may be of interest to estimate the contributions of pre-anthesis and post-anthesis assimilations to grain or grain $\mathrm{N}$ yields.

The values of $22-26 \%$ (table IV) calculated here to represent the pre-anthesis assimila- tion part of the grain are within the range of currently published results (Bidinger et al, 1977; Austin et al, 1980). This quantity is superior for the 6-row, but the difference is significant only in 1990. If the hypotheses formulated above are accepted, 2 explanations may be given:

- the 6-row grain DM ai flowering is higher. This quantity can be estimated to represent $8-9 \%$ of final grain yield (Bidinger et al, 1977). The 6-row 1000 -grain weight being lower, it is likely that their hulls are proportionally greater. Scott et al (1983) have shown that the part of the hulls in the final grain yield was greater in the lateral $(12-17 \%)$ than in the central kernels (10-13\%) of 6-row barley.

- the 6-row translocate to the grain a greater amount of assimilates previously stored in the vegetative parts. If it is assumed that chaff $D M$ is constant after flowering, it is possible to make another estimate of pre-anthesis assimilation (Daniels et al, 1982). Considering only the stem plus leaves DM makes it possible not to take into account the hulls in the estimate of the contribution of pre-anthesis assimilation to grain yield. The values thus obtained are similar in 1989 for the 2- and 6 -row (136 and $\left.131 \mathrm{~g} \cdot \mathrm{m}^{-2}\right)$. In 1990, the 6-row retranslocation was superior (174 compared to $156 \mathrm{~g} \cdot \mathrm{m}^{-2}$ ), but the difference was not significant. Therefore the 6-row better harvest index does not seem to be explained by a difference in pre-anthesis assimilation.

Table IV. Estimation of pre-anthesis and post-anthesis assimilation in 1989 and 1990 for the 2- and the 6-row (1st line: $\mathrm{g} \cdot \mathrm{m}^{-2}$, 2nd line: \% of grain yield or grain $\mathrm{N}$ yield). Within the same year, 2 means followed by the same letter are not significantly different at the $5 \%$ level.

\begin{tabular}{|c|c|c|c|c|}
\hline & \multicolumn{2}{|c|}{1989} & \multicolumn{2}{|c|}{1990} \\
\hline & 2-row & 6-row & 2-row & 6-row \\
\hline \multicolumn{5}{|l|}{ Aerial dry matter } \\
\hline Pre-anthesis assimilation & $\begin{array}{c}158^{\mathrm{a}} \\
(21.7)\end{array}$ & $\begin{array}{c}176^{a} \\
(22.7)\end{array}$ & $\begin{array}{c}183^{b} \\
(22.6)\end{array}$ & $\begin{array}{c}223^{\mathrm{a}} \\
(25.7)\end{array}$ \\
\hline Post-anthesis assimilation & $\begin{array}{c}569^{a^{\prime}} \\
(78.3)\end{array}$ & $\begin{array}{c}599^{a} \\
(77.3)\end{array}$ & $\begin{array}{c}627^{a} \\
(77.4)\end{array}$ & $\begin{array}{c}644^{a} \\
(74.4)\end{array}$ \\
\hline Grain yield & $\begin{array}{c}727^{b} \\
(100.0)\end{array}$ & $\begin{array}{c}775^{a} \\
(100.0)\end{array}$ & $\begin{array}{c}810^{b} \\
(100.0)\end{array}$ & $\begin{array}{c}866^{a} \\
(100.0)\end{array}$ \\
\hline \multicolumn{5}{|l|}{ Nitrogen } \\
\hline Pre-anthesis assimilation & $\begin{array}{c}12.3^{a} \\
(89.8)\end{array}$ & $\begin{array}{c}11.7^{\mathrm{a}} \\
(90.0)\end{array}$ & $\begin{array}{l}12.8^{\mathrm{a}} \\
(77.1)\end{array}$ & $\begin{array}{l}12.7^{\mathrm{a}} \\
(77.0)\end{array}$ \\
\hline Post-anthesis assimilation & $\begin{array}{r}1.4^{a} \\
(10.2)\end{array}$ & $\begin{array}{r}1.3^{a^{a}} \\
(10.0)\end{array}$ & $\begin{array}{c}3.8^{a^{\prime}} \\
(22.9)\end{array}$ & $\begin{array}{r}3.7^{a} \\
(23.0)\end{array}$ \\
\hline Grain $N$ yield & $\begin{array}{c}13.7^{a} \\
(100.0)\end{array}$ & $\begin{array}{c}13.0^{\mathrm{a}} \\
(100.0)\end{array}$ & $\begin{array}{c}16.6^{\mathrm{a}} \\
(100.0)\end{array}$ & $\begin{array}{c}16.5^{a} \\
(100.0)\end{array}$ \\
\hline
\end{tabular}


Post-anthesis assimilation is higher for the 6row than for the 2-row, but once again the difference is not significant. Photosynthetic activity after anthesis is therefore apparently not determinant in explaining the 6-row higher aboveground DM at maturity. The difference observed at anthesis remains the same until maturity.

From 80 to $90 \%$ of nitrogen in the grain is due to pre-anthesis assimilation. No difference has been shown between the 2 types of barley for this character.

\section{CONCLUSION}

Under intensive cultivation conditions and within the limits of the genotype sample of this study, the 6-row outyielded the 2-row. A better harvest index and a slightly higher DM production appear to be the cause of this difference. This trend is visible from anthesis onwards: the 6row have a higher above-ground DM and a proportionally greater ear DM. These results, obtained in one location over a 2-year period under similar weather conditions, need to be confirmed in other situations.

The quantity of assimilated $\mathrm{N}$ and its distribution in the plant seem to be equivalent between the 2 groups. When using barley grain for animal feeding or malting, protein concentration is a very important characteristic. If this factor is considered alone, the 6-row have an asset: a low concentration for malting and brewing and a high $\mathrm{N}$ yield for animal feeding. They have however some defects, (heterogeneity in grain size, husk percentage, etc) which often limit their nutritional or industrial quality.

The better grain yield of 6-row explains their prominence in potentially high-yield areas of France. Nevertheless, 2-row barley are still of some interest because of their generally superior lodging resistance and malting quality.

\section{ACKNOWLEDGMENTS}

I am greatly indebted to $M$ Leleu and $M$ Mériaux for their competent technical assistance and to $N$ Damay, M Derieux, M Hulmel, L Jestin, P Pluchard and $F$ Vear for their invaluable comments on this paper.

\section{REFERENCES}

Austin RB, Morgan CL, Ford MA, Blackwell RD (1980) Contributions to grain yield from preanthesis assimilation in tall and dwarf barley phenotypes in two contrasting seasons. Ann Bot $45,309-319$

Bachacou J, Masson JP, Millier C (1981) Manuel de la Programmathèque Statistique AMANCE. INRA, $516 \mathrm{p}$

Bidinger F, Musgrave RB, Fisher RA (1977) Contribution of stored pre-anthesis assimilate to grain yield in wheat and barley. Nature (Lond) $270,431-433$

Daniels RW, Alcock MB, Scarisbrick DH (1982) A reappraisal of stem reserve contribution to grain yield in spring barley (Hordeum vulgare L). J Agric Sci (Camb) 98, 347-355

Gallagher JN, Biscoe PV, Scott RK (1975) Barley and its environment. V. Stability of grain weight. $J$ Appl Ecol 12, 319-336

GNIS (1990) Actualité semences: céréales à paille. Sem Prog 65, 154

Gymer PT (1978) The genetics of the six-row/tworow character. Barley Genet News/ 8, 44-46

Hipps LE, Asrar G, Kanemasu ET (1983) Assessing the interception of photosynthetically active radiation in winter wheat. Agric Meteorol 28, 253-259

Jestin L (1985) Some aspects of adaptation and adaptability of barley in European conditions. Neth J Agric Sci 33, 195-213

McGuire CF, Hockett EA (1983) Relationship of V, $i$ and $L$ alleles with malting quality of Bonneville barley. Field Crop Res 7, 51-60

Nalborczyk E, Nalborczyk T, Wawrzonowska B (1981) Models of photosynthetic activity in cereals. In: Photosynthesis VI: Photosynthesis and Productivity. Photosynthesis and Environment. (Akoyunoglou, ed), Balaban Int Sci Services 97-106

Pomeranz Y, Robbins GS, Wesenberg DM, Hockett EA, Gilbertson JT, (1973 Amino acid composition of two-rowed and six-rowed barleys. Agric Food Chem 21, 218-221

Riggs TJ, Kirby EJM (1978) Developmental consequences of two-row and six-row ear type in spring barley. I. Genetical analysis and comparison of mature plant characters. J. Agric Sci (Camb) 91, 199-205

Russel G, Ellis RP (1988) The relationship between leaf canopy development and yield of barley. Ann Appl Biol 113, 357-374

Scott WR, Appleyard M, Fellowes G, Kirby EJM (1983) Effect of genotype and position of ear on carpel and grain growth and grain weight of 
spring barley. In: Barley genetics. J Agric Sci (Camb) 100, 383-391

Scriban R, Berbigier A, Jestin L, Denis JB, (1981) Étude de quelques caractères agronomiques et technologiques chez des variétés d'orge de printemps. Agronomie 1, 143-155

Takahashi R, Hayashi J, Moriya I (1976) Basic studies on breeding barley by the use of tworowed and six-rowed varietal crosses. In : Barley Genetics III 7-12 Juillet, Garching Germany. Proc 3rd Barley Genetics Symp (Gaul ed), Karl Heimig, Munich, 662-677
Thorne GN (1963) Varietal differences in photosynthesis of ears and leaves of barley. Ann Bot $27,155-174$

Varlet-Grancher C, Gosse G, Charlier M, Sinoquet $H$, Bonhomme R, Allirand JM (1989) Mise au point: rayonnement solaire absorbé ou intercepté par un couvert végétal. Agronomie 9, 419439

Williams RH, Hayes JD (1979) Relationships between photosynthetic area and other growth attributes with grain yield in 6 and 2 rows barley genotypes. Ann App/ Biol 91, 391-395

\section{APPENDIX}

Presentation of the main characteristics of the genotypes studied (data from the Groupe d'Étude et de Contrôle des Variétés et des Semences, except for Borwina and CF 84-234): name, code, breeder (B = Belgium, $\mathrm{G}=$ Germany, $\mathrm{F}=$ France), registration date (in Germany for Borwina), row number, vernalization requirement $(1=$ winter type, $9=$ spring type $)$ and earliness $(1=$ late, $9=$ early $)$.

\begin{tabular}{|c|c|c|c|c|c|c|}
\hline Name & Code & Breeder & Registration & Row & Venalization & Earliness \\
\hline Ager & $A G$ & INRA $(F)$ & 63 & 6 & 5 & 8 \\
\hline Alpha & al & INRA (F) & 72 & 2 & 5 & 7.5 \\
\hline Barberousse & $\mathrm{BA}$ & Ringot (F) & 77 & 6 & 4 & 8.5 \\
\hline Belivia & be & INRA $(F)$ & 86 & 2 & 4 & 7.5 \\
\hline Borwina & BO & VVB saat $(G)$ & 82 & 6 & (2) & (5) \\
\hline Celtic ${ }^{\star}$ & $\mathrm{CE}$ & Desprez (F) & 84 & 6 & 7 & 6 \\
\hline CF $84-234$ & CF & $\operatorname{INRA}(F)$ & - & 6 & - & (7) \\
\hline Clerix & $\mathrm{cl}$ & INRA(F) & 87 & 2 & 5 & 7.5 \\
\hline Eldorado & $E L$ & Unisigma (F) & 82 & 6 & 3.5 & 7.5 \\
\hline Express & EX & Serasem (F) & 85 & 6 & 6 & 7 \\
\hline Fedora* & $\mathrm{fe}$ & INRA $(F)$ & 86 & 2 & 8 & 6.5 \\
\hline Flamenco & $\mathrm{fl}$ & Secobra $(F)$ & 81 & 2 & 2 & 6.5 \\
\hline Gerbel & GE & Desprez (F) & 77 & 6 & 4.5 & 7 \\
\hline Glenan* & GL & Verneuil (F) & 88 & 6 & 5 & 7 \\
\hline Igri & ig & Ackermann (G) & 77 & 2 & 4 & 7 \\
\hline Jaidor & JA & INRA (F) & 81 & 6 & 8 & 7 \\
\hline Kaskade & $\mathrm{ka}$ & $\mathrm{BPZ}(\mathrm{G})$ & 85 & 2 & 4 & 5 \\
\hline Magie & $\mathrm{mg}$ & Serasem (F) & 83 & 2 & 3 & 6 \\
\hline Manitou* & $\mathrm{MI}$ & Secobra $(F)$ & 88 & 6 & 7 & 7 \\
\hline Marianne ${ }^{\star}$ & $\mathrm{mn}$ & Serasem (F) & 88 & 2 & 6 & 8 \\
\hline Marylin & $\mathrm{mr}$ & Franck (G) & 83 & 2 & 3.5 & 6.5 \\
\hline Matador ${ }^{*}$ & MT & Momont $(F)$ & 88 & 6 & 3 & 6 \\
\hline Mogador & mo & Secobra (F) & 80 & 2 & 3 & 7 \\
\hline Mosar* & $\mathrm{ms}$ & Secobra (F) & 85 & 2 & 3 & 8 \\
\hline Panda* & pn & Desprez (F) & 81 & 2 & 8 & 6 \\
\hline Pastoral & pa & Secobra (F) & 86 & 2 & 4 & 7 \\
\hline Plaisant & PL & GAE (F) & 79 & 6 & 5.5 & 7.5 \\
\hline Rebelle* & RE & Serasem $(F)$ & 88 & 6 & 5 & 7.5 \\
\hline Robur & RO & INRA $(F)$ & 73 & 6 & 5 & 8.5 \\
\hline Smash & SM & SES (B) & 84 & 6 & 4.5 & 8 \\
\hline Sonja & so & Engelen (G) & 74 & 2 & 3.5 & 6.5 \\
\hline
\end{tabular}

\footnotetext{
Varieties studied only in 1990.
} 